\title{
PAKPAK LANGUAGE TRANSLATOR APPLICATION INTO INDONESIAN USING ALGORITHMBOYER MOORE BASED ON ANDROID
}

\author{
Khairani Purba ${ }^{1}$, Charles Jhony Mantho Sianturi ${ }^{2 *}$, Mikha Dayan Sinaga ${ }^{3}$, \\ Nita Sari Sembiring4 ${ }^{4}$ Erwing Ginting ${ }^{5}$, Muhammad Fauzi ${ }^{6}$ \\ 1,2,3,4,5,6 Jurusan Teknik Informatika \\ Universitas Potensi Utama \\ https://potensi-utama.ac.id/ \\ khairani0610@gmail.com ${ }^{1}, 79$ sianturi@gmail.com ${ }_{2}{ }_{2}$ mikhadayan88@gmail.com ${ }_{2}{ }_{2}$ \\ nita.sembiring86@gmail.com ${ }^{4}$,erwinginting82@gmail.com ${ }^{5}$, mfauzixx@gmail.com ${ }^{6}$
}

\begin{abstract}
Abstrak
Minimnya pelestarian juga pengetahuan mengenai Bahasa Pakpak di Indonesia yang menyebabkan Bahasa Pakpak kelestariannya kurang terjaga terutama bagi para kalangan muda yang terus mengikuti perkembangan zaman. Hal ini menyebabkan proses globalisasi dan urbanisasi yang menyebabkan terjadinya asimilasi dan akulturasi budaya, khususnya daerah perkotaan. Keadaan ini memicu bahasa baru yang sangat disukai terutama bagi kalangan muda yang tanpa disadari hal tersebut membuat kita kehilangan identitas sebagai masyarakat yang memiliki suku dan adat istiadat masing - masing dan munculnya sekolah internasional dan nasional yang mengharuskan siswanya berbahasa asing. Sebab itu, dibutuhkannya pembelajaran untuk menjaga kelestarian Bahasa Pakpak. Dengan cara membuat aplikasi penerjemah Bahasa Pakpak ke Bahasa Indonesia yang memakai algoritma Boyer Moore Berbasis Android. Aplikasi penerjemah ini dibuat untuk pengenalan Bahasa Pakpak untuk masyarakat luas sehingga membuat Bahasa Pakpak kelestariannya tetap terjaga dan aplikasi penerjemah ini bias menerjemahkan Bahasa Pakpak ke Bahasa Indonesia atau sebaliknya yang berdasarkan kamus Pakpak - Indonesia yang berlaku.
\end{abstract}

Kata Kunci: Bahasa Pakpak, Bahasa Indonesia, Algoritma Boyer Moore, Android

\begin{abstract}
The lack of preservation is also the knowledge of the Pakpak Language in Indonesia, which causes the Pakpak Language to be less preserved, especially for young people who continue to keep abreast of the times. This causes the process of globalization and urbanization which causes assimilation and acculturation, especially in urban areas. This situation triggers a new language that is very popular, especially for young people who unconsciously, it makes us lose our identity as a society that has tribes and customs each - and the emergence of international and national schools that require students to speak foreign languages. Therefore, learning is needed to preserve Pakpak Language. By making a Pakpak to Indonesian translator application that uses the Android Based Boyer Moore algorithm. This translator application was made for the introduction of the PakpakLangugae to the wider community so that the sustainability of the Pakpak Language is maintained and this translator application can translate the Pakpak Language into Indonesian or vice versa based on the prevailing Pakpak - Indonesian dictionary.
\end{abstract}

Keywords: Pakpak Language, Indonesian, Boyer Moore's Algorithm, Android

\section{INTRODUCTION}

Regional languages are a means of communication for every ethnic/tribe in Indonesia. Regional languages are rarely used as a means of communication when they are overseas, especially the Pakpak language. Given that the Pakpak language has begun to be abandoned, where most of the younger generation are less aware of the importance of regional languages. The Pakpak language translator application into Indonesian is designed to translate words and sentences where this application has 2 features, namely Pakpak Indonesian and Indonesian - Pakpak by applying the Boyer Moore Algorithm. With this application, it can help in the communication process between anyone who does not understand the Pakpak language and introduces regional languages, especially the Pakpak language.

As a type of art, literature has existed in the course of human civilization. The process of education, introduction, and understanding of 
literature will be able to enrich humans as individuals in continuous dialogue with the human world and humanity. In this context, literature has the potential as a transmitter of various values and can be a source of inspiration about virtue and wisdom (Sukirman, 2021).

Regional languages also have an important role in shaping human character. Regional languages are part of a culture that lives and develops according to the needs of the community. However, in this era of globalization, there is concern from language observers that many regional languages are threatened with extinction. This anxiety deserves attention because the loss of a regional language is an indication of the loss of world culture and civilization (Nikmatuzaroh, 2018).

The phenomenon of the extinction of regional languages in Indonesia seems to have become a problem that has attracted the attention of many scientists, especially linguists. Various efforts have been and are being made to save regional languages which tend to lead to the process of extinction. Of course, it is quite reasonable considering that Indonesia is a country that has the second most regional languages in the world after Papua New Guinea(Tondo, 2009).

The division (read: division) of Dairi Regency into two regencies is a political decision (action) involving the Pakpak ethnic group or the Pakpak people. The political action that gave birth to West Pakpak Regency as a new division, and Dairi Regency as the parent regency, was confirmed by Law of the Republic of Indonesia Number 9 of 2003 concerning the Establishment of South Nias Regency, Pakpak Bharat Regency, and Humbang Hasundutan Regency in North Sumatra Province. The expansion of Dairi Regency is inseparable from the official implementation in 2001 of Law No. 22 of 1999 concerning Regional Government(Zuska, 2013).

In Ida Basaria's research, I want to examine the pragmatic functions of the Pakpak Dairi language (hereinafter referred to as BPD), so that it will be known whether BPD belongs to a language group that emphasizes a subject (subject prominent language) or a language group that highlights a topic (topic prominent language). The study is based on the theoretical framework of language typology about the difference between language that emphasizes the subject and language that emphasizes(Basaria, 2014).

Regional languages are a valuable asset of a nation. However, the paradigm of 21st-century society views that foreign languages have higher prestige than national and regional languages. In other words, regional languages are the third priority in their use after national and foreign languages. The preservation of regional languages is one of the phenomena as well as steps that arise in the mindset of the polemic of a shift in regional languages(Widianto, 2018).

The government cannot maintain the regional language without the awareness of the speakers to maintain the regional language itself. The role and contribution of local language users itself greatly affect the success of local language defense(Alimin \& Fajri, 2020).

The translation is the process of transferring language, word by word from one language to another. Another theory states that translation is an activity of replacing text/speech/speech material in the source language to equivalent text/speech/speech material into the target language. (Priyanto \& Ulinnuha, 2017).

Research from Muhammad Zulham, Helmi Kurniawan, and Iwan Fitrianto Rahmad entitled Design of Email Data Security Applications Using Android-Based RC6 Encryption Algorithm. The purpose of this study is to secure messages that will be encoded on email in data confidentiality and can send messages and receive messages through email intermediaries using the rc6 android application. (Zulham et al., 2014).

Based on the research entitled "Implementation of the Salsa20 Stream Cipher Cryptographic Technique for Database Security". This study concludes that the Salsa20 stream cipher cryptographic technique can be used to provide increased data security through the encryptiondecryption process before the data is stored in a database. Cryptographic techniques with the Stream Cipher Algorithm method can be applied to ensure the security of electronic document files. One that can be used is the encryption and decryption of text data or in other words, encoding the data so that only the intended person can know the contents of the data. (Munandar et al., 2020).

Research conducted by Asbon Hendra and Ratih Adinda Destari entitled Expert System to Identify Ariston Water Heater Damage Using WebBased Backward Chaining Method. From the research conducted, it is stated that the application is built using the backward chaining method and several programming languages such as php, mysql and others. So it doesn't take long and gives a good impact(Hendra \& Destari, 2015).

Research conducted by Khairani Puspita and M. Rhifky Wayahdi entitled Analysis of the Combination of Ceaser Cipher, Vernam Cipher and Hill Cipher Methods in the Cryptographic Process. In this study caesar cipher, vernam cipher, hill cipher are classical cryptography. This method is very strong in security and has security that is very 
difficult to break and can be modified and combined(Puspita \& Wayahdi, 2015).

The Boyer-Moore algorithm is a string search algorithm, published by Robert S. Boyer, and J. Strother Moore in 1977. This algorithm is considered the most efficient algorithm in general applications (Argakusumah \& Hansun, 2014). Unlike the string search algorithm found previously, the Boyer-Moore algorithm starts matching characters from the right of the pattern (the pattern you are looking for). (Ramadhansyah, 2013). The idea behind this algorithm is that by starting character matching from the right, and not from the left, more information will be obtained (Darmawan et al., 2018).

Boyer-Moore algorithm is famous because it is widely applied to the matching algorithm for many strings (multiple patterns). The basic idea of the Boyer-Moore algorithm is as simple as the Brute Force algorithm by using the help of a table containing the steps for moving the pattern to the right when it encounters a character mismatch. (Ardi et al., 2017).

Android is a subset of software for mobile devices that includes an operating system, middleware, and core applications released by Google. Android is a mobile operating system that adopts the Linux operating system but has been modified(Lengkong et al., 2015).

The purpose of this research is to introduce and provide knowledge about the Pakpak language, assist in communicating with people who use the Pakpak tribal language, apply the Boyer Moore
Algorithm in translating Pakpak language into Indonesian, build an application that can translate Pakpak language into Indonesian using the Boyer Moore method, and building an application that can translate Pakpak language into Indonesian using the Android-based Boyer Moore method.

\section{RESEARCH METHODS}

\section{Data collection}

At this stage the author also collects data through:

1. Field study

This research is a direct study to see or review the location. Data collection techniques are as follows:

a) Interviews, namely holding questions and answers to related sources. Mr. Drs. Amhar Kudadiri, M.Hum who knows about Pakpak culture and language and is the secretary of the literature study program, faculty of science and culture at the University of North Sumatra.

b) Observations, namely by observing the Pakpak people in North Sumatra, especially in the Medan city area.

\section{Literature Study}

This stage is carried out to collect data on writing this thesis through articles, books, journals and others.

\section{Design Procedure}

This analysis is carried out to determine the stages of research completion, as shown in Figure 1:

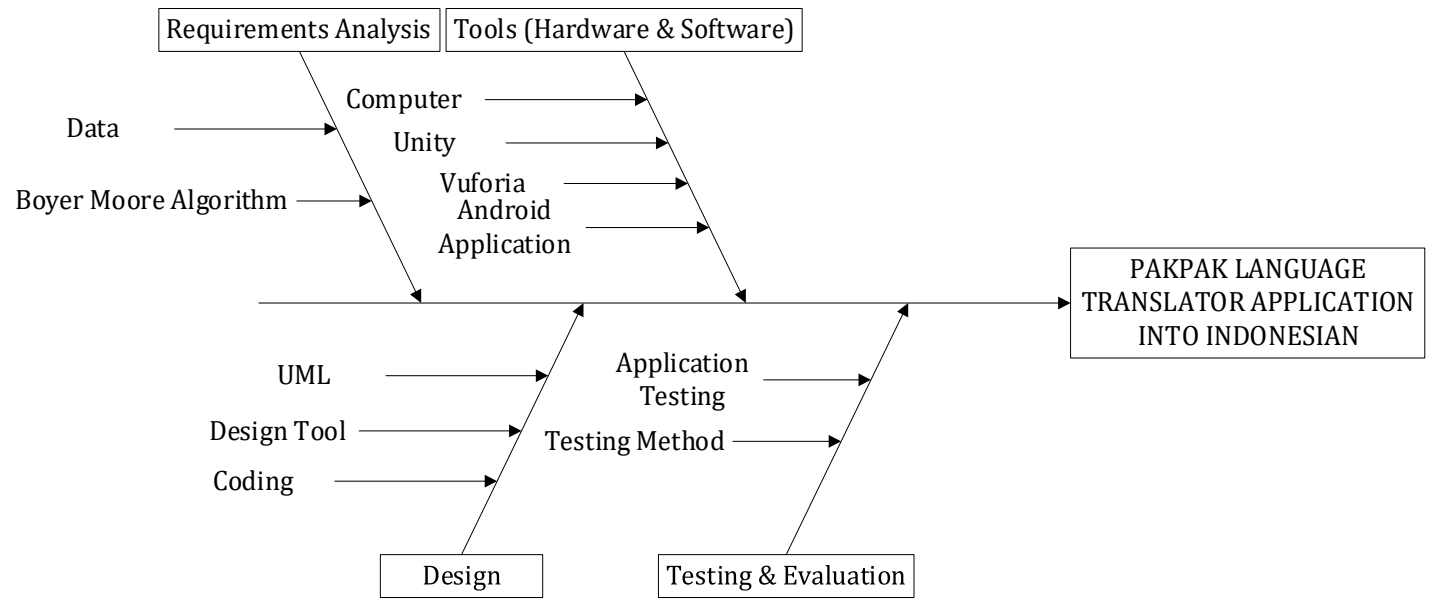

Figure 1. Fishbone Diagram Research

\section{RESEARCH RESULTS AND DISCUSSION}

\section{Discussion}

a. Boyer Moore Algorithm Method
Boyer Moore algorithm can be seen in the Figure 2 flowchart as follows.

Figure 2 it can be seen the Boyer Moore process contained in the system to be built. First, enter the 
pattern in the form of characters to be able to do a string search. Then read the pattern on the text in SQLite, whether the searched string is a match in the text. Performs string matching from right to left according to the input pattern desired by the user.

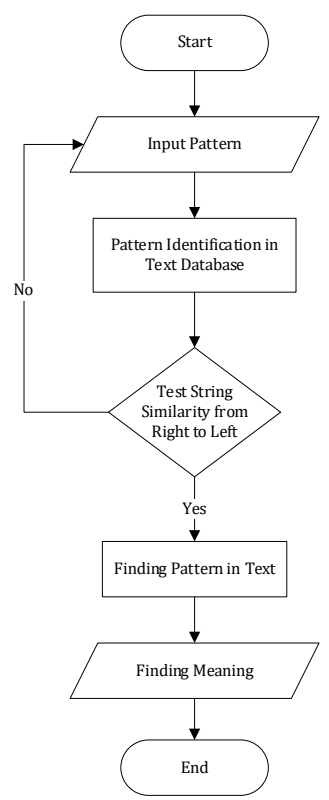

Figure 2. Flowchart Diagram of Boyer Moore Algorithm

This is done until the pattern you are looking for is matched. After doing the matching, the pattern will get a match on the available text. Where there has been grouping of data to directly know the meaning. Finally, the system issues an output, where the system automatically issues all options based on the inputted pattern and displays the translation results based on the search process using the Boyer Moore algorithm.

\section{b. System Modeling}

1) Use case diagram

Use case diagrams are used to see a sequence of systems built and can see the related relationships. The use case diagram of the research can be seen in Figure 3 below.

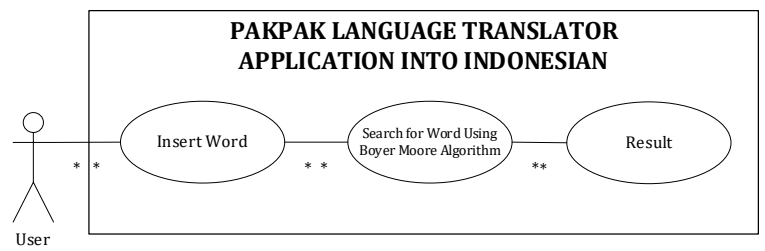

Figure 3. Use case diagram of the Pakpak to Indonesian Translator Application

\section{2) Activity Diagram}

Activity diagram is a process that explains the various related flows in the system that will be designed from the beginning to the end, it can be seen in Figure 4:

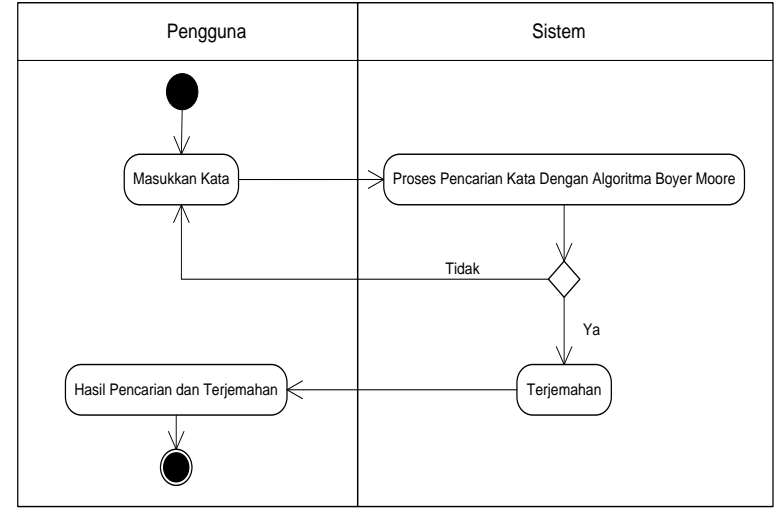

Figure 4. Activity diagram of the Pakpak Language Translator Application to Indonesian

\section{Sequence diagram}

Sequence diagram displays the interaction between objects in the system built, can be seen in Figure 5:

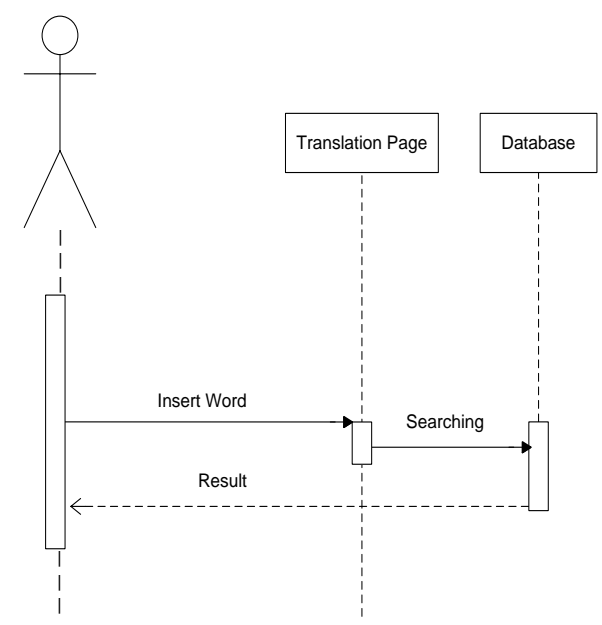

Figure 5. Sequence Diagram of the Pakpak to Indonesian Translator Application

\section{Results}

a. User Interface

These results are used to show the appearance of the Pakpak language translator application into Indonesian using the Android-based Boyer Moore algorithm. The following will explain the display of the results of the Pakpak language translator application into Indonesian.

1) Splash screen

Splash screen is the display that will appear the first time when we run the Pakpak language translator application into Indonesian based on Android, it can be seen in Figure 6: 


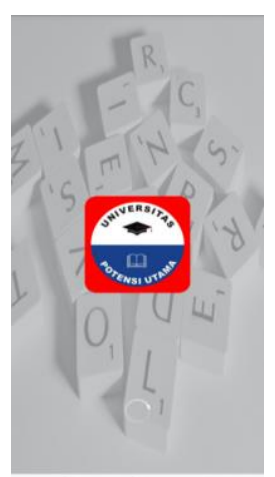

Figure 6. Splash Screen Display

\section{2) Main page}

The main page of the application has several menu options such as the homepage, Pakpak Indonesian translator, Pakpak Indonesian translator, about and exit, can be seen in Figure 7 .

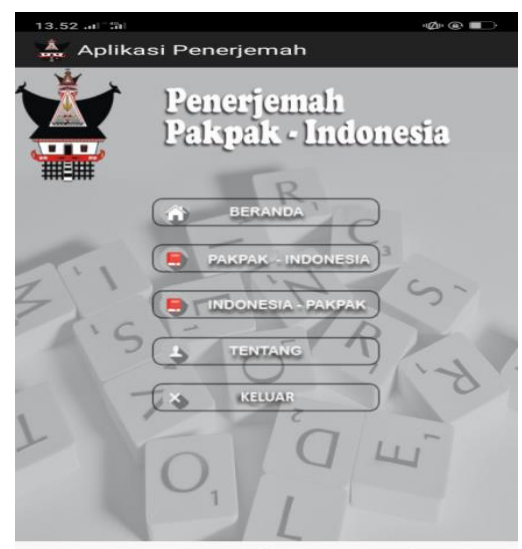

\section{3) Home}

Figure 7. Main Page Display

When the home menu is clicked by the user, it will display information at a glance about a brief explanation of the translator application, which can be seen in Figure 8:

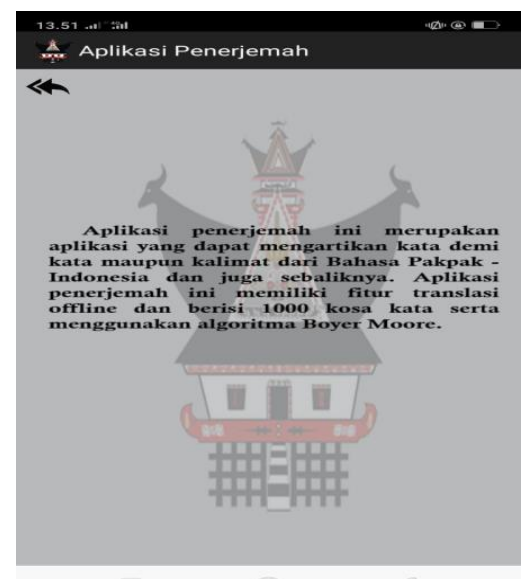

Figure 8. Home View

4) Pakpak - Indonesia

This page shows that testing the Boyer Moore algorithm for translating Pakpak language into Indonesian can display perfect translation results as in the SQLite database, can be seen in Figure 9:

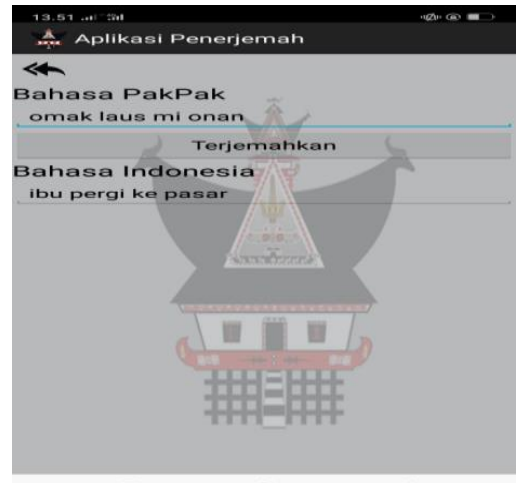

Figure 9. Pakpak Display - Indonesia

5) Indonesia - Pakpak

This display shows that testing the Boyer Moore algorithm for translating Indonesian into Pakpak language can display perfect translation results such as those in the SQLite database, can be seen in Figure 10:

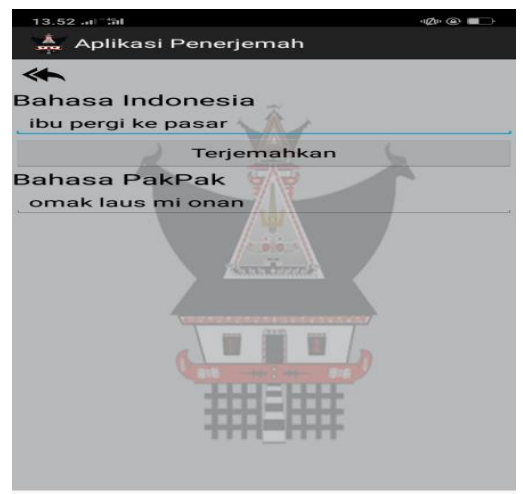

Figure 10. Indonesian Display - Pakpak

6) About

This page contains the author's information briefly such as name, number, study program, address and email, you can see Figure 11: 


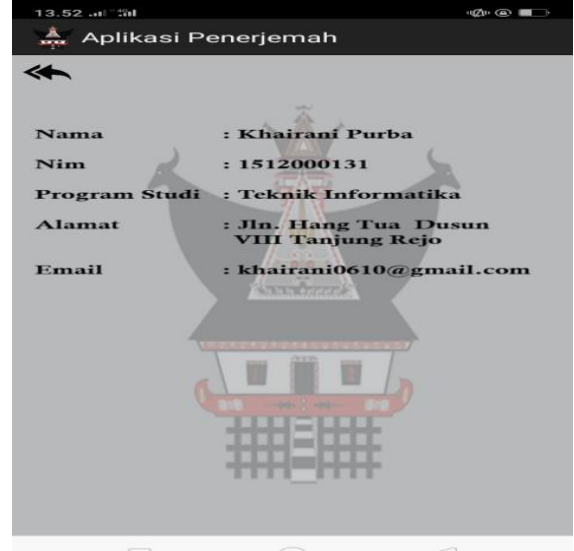

Figure 11. Display About

\section{c. Testing}

This trial is carried out to find out the system designed is in good condition or condition or not and if it is in accordance with what was built it can be used, this application test is carried out using blackbox testing:

Table 1. Application test plan

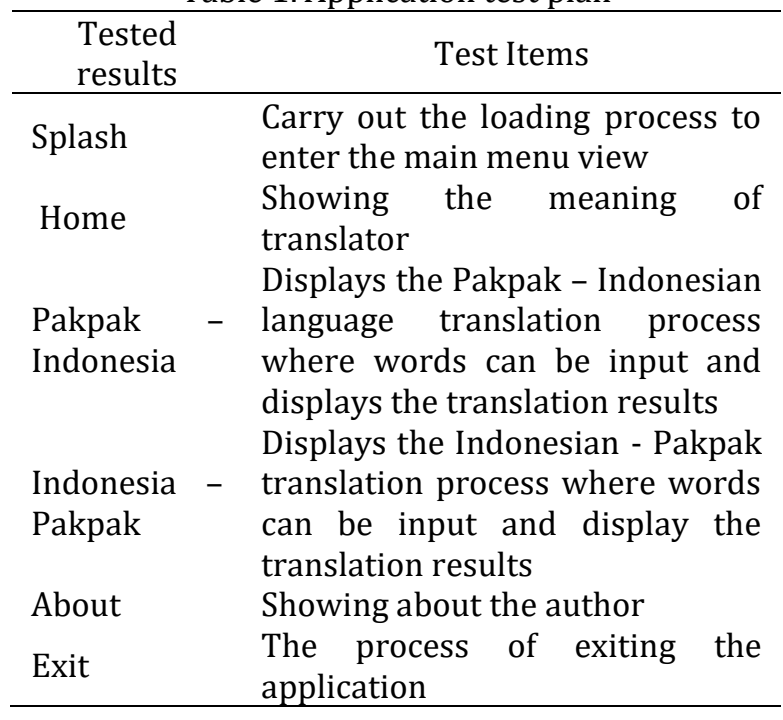

\section{CONCLUSIONS AND SUGGESTIONS}

\section{Conclusion}

From the discussion and trials that have been made, it can be concluded that the Boyer Moore algorithm can be used to complete the translation of words or sentences and this application system performs the process of translating words or sentences based on the vocabulary in the SQLite database in the application. This language translator application has been successfully built and can be used as a learning medium to make it easier for people to know the local language, namely Pakpak Language.

\section{Suggestion}

In order to improve the designed application, suggestions are given, such as further development of the addition of copy, cut, text to speech, and other additional features, and in the translator application. Pakpak language into Indonesian so that it can be further developed in terms of adding information or information to the word you are looking for. To be able to use language more effectively on vocabulary.

\section{ACKNOWLEDGMENTS}

The author would like to thank the University of Potential Utama for giving me the opportunity to complete this research.

\section{REFERENCE}

Alimin, R., \& Fajri, R. (2020). Pergeseran Dan Pemertahanan Bahasa Pakpak Dialek Boang Di Kecamatan Rundeng Kota Subulussalam. Journal of Education Science, 8(1), 429-441. http://www.jurnal.unsyiah.ac.id/MB/article /view/22155

Ardi, Y., Andreswari, D., \& Setiawan, Y. (2017). Rancang Bangun Aplikasi Kamus Istilah Kedokteran Dengan Menggunakan Algoritma Boyer-Moore Berbasis Android. Jurnal Rekursif, 5(3), 346-359.

Argakusumah, K. W., \& Hansun, S. (2014). Implementasi Algoritma Boyer-Moore pada Aplikasi Kamus Kedokteran Berbasis Android. Ultimatics (Jurnal Teknik Informatika), 6(2), 70-78. https://doi.org/10.31937/ti.v6i2.340

Basaria, I. (2014). Pentopikalan Dalam Bahasa PAKPAK-DAIRI. LITERA, 13(1), 140-154. https://journal.uny.ac.id/index.php/litera/ar ticle/view/1909/1564

Darmawan, R. I., Setianingrum, A. H., \& Arini, A. (2018). Implementasi Algoritma Boyer Moore Pada Aplikasi Kamus Istilah Kebidanan Berbasis Web. QUERY: Jurnal Sistem Informasi, 2(1), 53-62. http://jurnal.uinsu.ac.id/index.php/query/a rticle/view/1574

Hendra, A., \& Destari, R. A. (2015). Sistem Pakar Pengidentifikasi Kerusakan Water Heater Ariston Dengan Menggunakan Metode Backward Chaining Berbasis Web. CSRID (Computer Science Research and Its Development Journal), 5(1), 11-30. http://piwik.potensi- 
utama.ac.id/index.php/CSRID/article/view/ 33

Lengkong, H. N., Sinsuw, A. A. E., \& Lumenta, A. S. . (2015). Perancangan Penunjuk Rute Pada Kendaraan Pribadi Menggunakan Aplikasi Mobile GIS Berbasis Android Yang Terintegrasi Pada Google Maps. E-Journal Teknik Elektro Dan Komputer, 2015(2015), 18-25.

Munandar, A., Rosnelly, R., \& Sianturi, C. J. M. (2020). Rancang Bangun Aplikasi Keamanan Data Teks Menggunakan Algoritma Stream Cipher. Jurnal Mahasiswa Fakultas Teknik Dan Ilmu Komputer, 1(1), 407-416. http://ejournal.potensi-

utama.ac.id/ojs/index.php/FTIK/article/vie $\mathrm{w} / 876$

Nikmatuzaroh, R. E. (2018). Evaluasi Tingkat Kepuasan Pasien Terhadap Pelayanan Kefarmasian Di Apotek Wilayah Kota Yogyakarta Provinsi Daerah Istimewa Yogyakarta. In FKIK UMY. Universitas Muhammadiyah Yogyakarta.

Priyanto, A., \& Ulinnuha, F. (2017). Perancangan Aplikasi Penerjemah Bahasa Indonesia Ke Bahasa Jawa Untuk Media Bantu Belajar Siswa SMK Salafiyah Berbasis Android. Ijns.Org Indonesian Journal on Networking and Security, 6(4), 2302-5700.

Puspita, \& Wayahdi, M. R. (2015). Analisis Kombinasi Metode Caesar Cipher, Vernam Cipher , Dan Hill Cipher Dalam Proses Kriptografi. Seminar Nasional Teknologi Informasi Dan Multimedia 2015, Februari, 4348.

https://www.academia.edu/download/3658 3960/Analisis_Kombinasi_Metode_Caesar_Ci pher_Vernam_Cipher_Dan_Hill_Cipher_Dala m_Proses_Kriptografi.pdf

Ramadhansyah. (2013). Perancangan Aplikasi Kamus Bahasa Gayo Dengan Menggunakan Metode Boyer-Moore. Teknik Informatika, STMIK Budidarma Medan, IV(12110817), 118-122.

Sukirman, S. (2021). Karya Sastra Media Pendidikan Karakter bagi Peserta Didik | Jurnal Konsepsi. Jurnal Konsepsi, 10(1), 1727.

https://p3i.my.id/index.php/konsepsi/articl e/view/4

Tondo, F. H. (2009). Kepunahan Bahasa-Bahasa Daerah: Faktor Penyebab Dan Implikasi Etnolinguistis. Jurnal Masyarakat \& Budaya, 11(2), 277-296.

Widianto, E. (2018). Pemertahanan Bahasa Daerah melalui Pembelajaran dan Kegiatan di Sekolah. Jurnal Kredo, 1(2), 1-13. http://jurnal.umk.ac.id/index.php/kredo/art icle/view/2096

Zulham, M., Kurniawan, H., \& Rahmad, I. F. (2014). Perancangan Aplikasi Keamanan Data Email Menggunakan Algoritma Enkripsi RC6 Berbasis Android. Seminar Nasional Informatika, 1(1), 96-101. http://ejournal.potensi-

utama.ac.id/ojs/index.php/SNIf/article/view $/ 221$

Zuska, F. (2013). Politik Etnisitas dalam Pemekaran Daerah. Antropologi Indonesia, 33(3). https://doi.org/10.7454/ai.v33i3.2464 
